\title{
Evaluation of the Biological and Ecological Characteristics of Plants Tulipa Biebersteiniana Schult. Et schult. Fil. Thelocal Population of the Belgorod Region
}

\author{
Tatyana N. Glubsheva ${ }^{1 *}$, Nikolay I. Sidelnikov ${ }^{1,2}$, Vladimir I. Cherniavskih ${ }^{1,3}$, Elena V. \\ Dumacheva $^{1}$, Svetlana E. Grigorenko ${ }^{1}$ \\ ${ }^{1}$ Belgorod State University 85, Pobedy St., Belgorod, 308015, Russia \\ ${ }^{2}$ All-Russian Scientific Research Institute of Medicinal and Aromatic Plants 7, Grina St., Moscow, 117216, Russia \\ ${ }^{3}$ All-Russian Research Institute of Phytopathology 5 Ownership, Institute St., r.p. Big Vyazemy, Odintsovo district, Moscow region, 143050, \\ Russia
}

\begin{abstract}
The problem of identification and determination of the habitat of the Red book species Tulipa biebersteiniana is revealed. A morphological description of the species found on the territory of the Belgorod region is given. Through the assessment of morphometric features, numerical characteristics of populations, parameters of life strategy, the hypothesis of bioecological differences in populations is put forward.
\end{abstract}

Keywords: Tulipa biebersteiniana, Red Book of the Belgorod region, Bulb, Local populations, Occurrence

\section{Introduction}

On the territory of the Belgorod region, there is one species of the genus Tulipa: bieberstein's Tulip (Tulipa biebersteiniana Schult. Et Schult. Fil). The species is listed in the Red Book of the Belgorod region with the category of rarity 2 "vulnerable" 2 (VS). The Eurasian steppe species is declining in number and in the number of localities [1]. The primary center of origin of wild tulips is considered to be the steppe and mountainous regions of Iran and the Tien Shan. They appeared for the first time in the late Miocene - early Pliocene epoch, i.e. 10-20 million years ago, representatives of this genus spread to the Western coast of southern Europe, North Africa, India, and China [2]. Most species grow in Central Asia and Kazakhstan, Iran, Afghanistan, the Mediterranean coast of Europe and North Africa, and Asia Minor. Some types of tulips are also found in the Caucasus, the Volga region, Western and Eastern Siberia, and the North-Western regions of Mongolia and China [3]. The dispersal of the Tulip led to the development of new conditions, adaptation to them and the appearance of differences that reach the level of species. According to M. V. Bochantseva [4], in the former Soviet Union, there were three major centers of formation. The first center was named desert-steppe, which includes the Baldara, Balkhash, Kyzylkum and Karakum regions. Species of European habitats are adjacent to this group. They have a starry yellow flower, a certain number of narrow leaves, polyploidy occurs. The second focus is defined by the Tien Shan. The third major center is considered to be the PamirAltai, with adjacent Turkmenistan and the Caucasus, whose plants are distinguished by the presence of a crimson hue in the petals, abundant pubescence of the integumentary scales [4].
Formative processes are still ongoing, as evidenced by discussions about the species belonging to individual specimens, the discrepancy in the total number of species.

The taxonomy of the genus is extremely complex and is associated with both objective and subjective factors. Types of tulips are highly variable, frequent cases of hybridization. The description of the species was carried out by various scientists, that causes the subjectivity of perception of some features, often unverified samples were used as standards. In different years, the systematic structure was presented in different ways. V. I. Vvedenskij [5] within the genus identified 6 sections Tulipanum, Leoistemones, Spiranthera, Lophohyllon, Eriostemones, Orithyia combining 63 species. Z.M. Silina [6] notes 140 species in the genus. According to the curators of the Kew Botanic gardens of the Royal horticultural society, the genus Tulipa includes 76 species and is divided into four subgenera: Clusianae (Baker) Zoon. Eriostemones (Bioss.) Raamsd., Orithyia (D. Don) Baker and Tulipa [7]. M. V. Baranova [3] indicates the presence of more than 100 species within the genus. Tulipa biebersteiniana Schult. Et Schult. fil. is an East European - Asian species, a stolon-forming oligo or polycarpic spring ephemeroid-geophyte. The first description was given in 1829 by father and son Shultes based on samples from the North Caucasus. The species was named after one of the first collectors, the prominent Russian botanist F. K. Biberstein-Marshal, who studied the flora of the Caucasus. Throughout its range, the species is highly variable and Tulipa biebersteiniana is also referred to as Tulipa graniticola (Klok.\&Zoz) Klok., T. hypanica Klok.\&Zoz., T. ophiophylla subsp. Bestashica Klok.\&Zoz., T. hypanica

Corresponding author: Tatyana N. Glubsheva, Belgorod State University 85, Pobedy St., Belgorod, 308015, Russia. E-mail: glubsheva@bsu.edu.ru 
Klok.\&Zoz., T. ophiophylla subsp. Graniticola Klok.\&Zoz, T. quercetorum (Klok.\&Zoz), T. scythica (Klok.\&Zoz) [8]. Common habitats, the ability to form interspecific hybrids, and the peculiarities of biology raise doubts among biologists of different specialties. Discussions about the relationship and unity of these species are now intensified in connection with the use of new genetic methods [9-16].

The range of the species is quite extensive. It is found in South-Eastern Europe (Romania, Transnistria), Eastern Europe (Ukraine, Russia), southern North Asia (Turkey), SouthWestern Asia (Northern Iran), the Caucasus (Georgia, Azerbaijan). In Russia, the Tulipa biebersteiniana is found in the territories of Astrakhan, Belgorod, Moscow, Volgograd, Voronezh, Kurgan, Lipetsk, Orenburg, Penza, Rostov, Samara, Saratov, Tambov, Ulyanovsk, Chelyabinsk regions, the republics of Dagestan, Ingushetia, Kalmykia, Crimea, Mordovia, North Ossetia-Alania, Tatarstan, the Chechen Republic, as well as Krasnodar and Stavropol territories (Fig. 1).

As can be seen from figure 1, the Belgorod region is the territory of the North-Western range of the species. Within the region, the species is found in the Eastern regions. Elinevsky and Chaadaeva [17], Kolchanov, Gusev [18], Chernyavskikh and Dumacheva [19] indicate the location of the species. The purpose of our study was to find out the bioecological features of local populations of Tulipa biebersteiniana on the border of the range in various conditions of the Belgorod region. Tasks are the following: (a) to identify morphometric differences within the species within local populations; (b) to estimate the number of species in the study areas; and (c) to determine the life strategy of local populations.

\section{Material and Methods}

The methodological basis of the research was the theory of the formation of a secondary anthropogenic Microgen center of formation in the South of the Central Russian upland [20-22]. The study of the species was conducted for three years on the territory of Veidelevsky and Krasnogvardeisky districts. In total, 7 local populations were studied, 20 traits were evaluated, and biological material was collected for further research. This was laid on a stationary platform: the girder at Viktoropol settlement, the tallweg in rural area Klimenki between the girder "Upravitel'stvennaya" and the forest in the rural area Klimenk, girder "Upravitel'stvennaya", a shrub on top of the girder of the rural area Malobykovo, the Budennovskij forest edge in front of the city of Biryuch, the roadside of the new road of the city of Biryuch, the forest of the rural area Klimenki. The size of stationary platforms is $100 \mathrm{~m}^{2}$. The research was carried out during the flowering period-fruit formation. The density was determined on 5-10 test plots with an area of $1 \mathrm{~m}^{2}$, the occurrence was determined on 30 test sites, and the total number of individuals in populations was determined taking into account the occurrence.

\section{Results and Discussion}

All populations identified according to morphological characteristics belong to the species Tulipa biebersteiniana and correspond to the descriptions given by A. I. Vvedenskij [5], Z. P. Bochantseva [4], I. A. Gubanov [23]. Plants are represented by a small bulb and a short-term developing shoot. Plants 15$33 \mathrm{~cm}$ high.

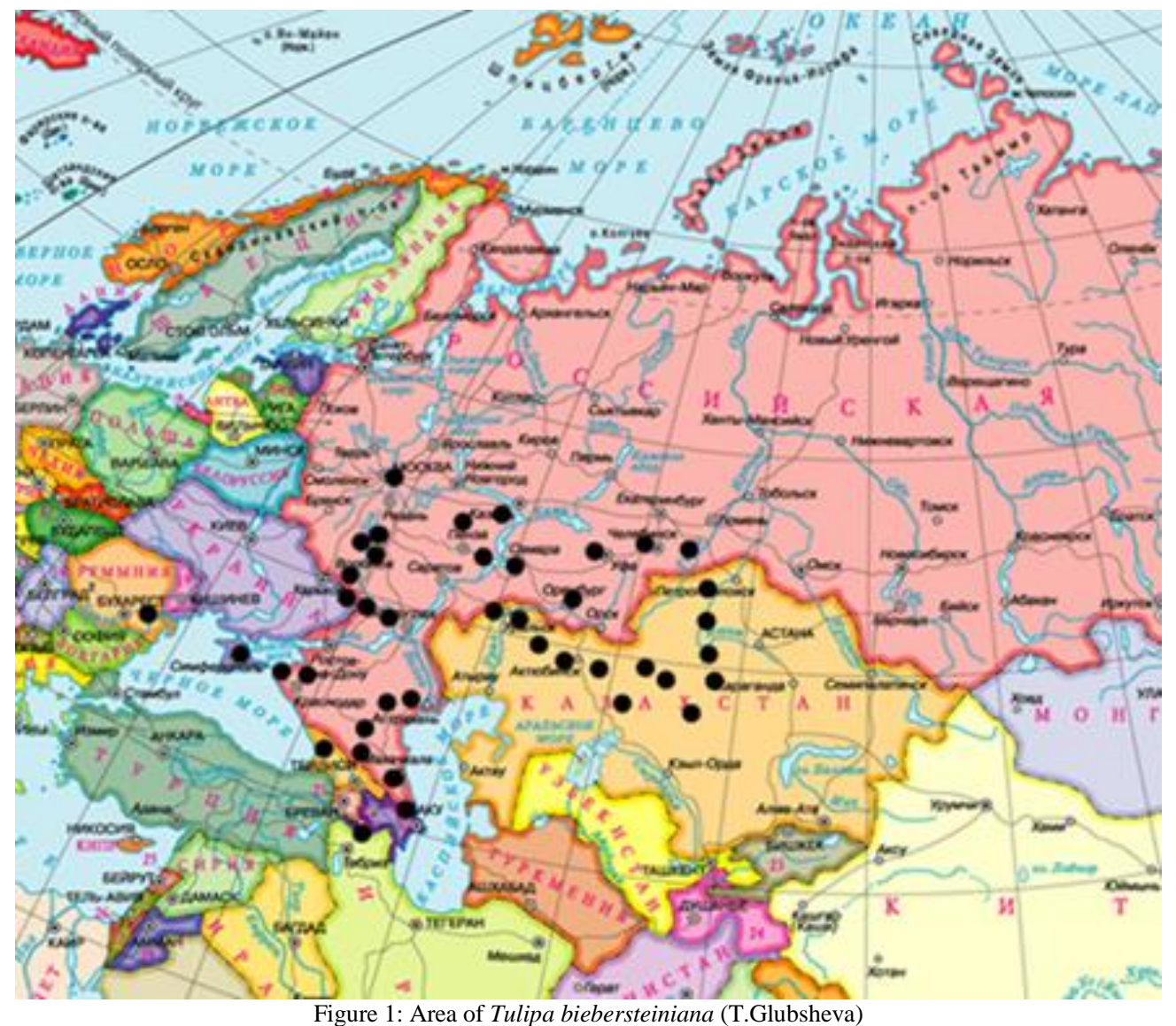

Figure 1: Area of Tulipa biebersteiniana (T.Glubsheva) 
The aboveground part is represented by a single leaf or shoot with two or three grooved leaves. Flower starry single, drooping in the Bud. Leaves of a simple perianth are Goldenyellow, outer on the outer side with a brownish-green tint. The stamens are arranged in two circles, the stamens of the inner circle are long, and the outer circle is short [24-26]. The flower length is $2.6-3.3 \mathrm{~cm}$ (Fig. 2). This trait is relatively stable both within populations and throughout the study. Young plants are able to form stolons. A population consisting of pregenerative individuals was found in the girder at Viktoropol village, consisting of pregenerative, so it causes the average height of about $15 \mathrm{~cm}$ and small bulbs $1.5 \mathrm{~cm}$ high, short and narrow leaves. The occurrence of plants is $7 \%$, the density of 47 pieces per $\mathrm{m}^{2}$. Half of the plants formed stolons, which indicates the number of immature and virginal plants. In the population 56 $\%$ of plants are juvenile and senile (Table $1,2,3$ ). The ratio in the population of plants at different stages of ontogenesis determines the shift of the age spectrum to the left. The absence of flowering plants may be due to mechanical damage to large generative bulbs during grazing.

The population at the forest edge in front of the entry of the city of Biryuch is numerous with a density of 30.5 pieces per $\mathrm{m}^{2}$ and a frequency of $10 \%$. As this space is the edge of the southern exposure, it is likely that low-growing plants (on

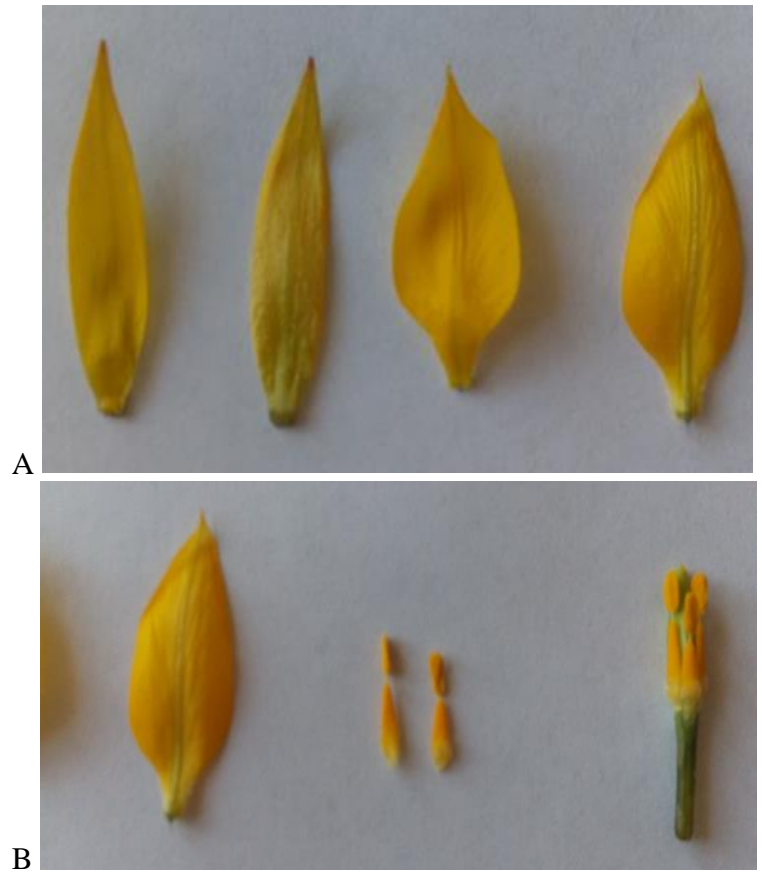

average $20 \mathrm{~cm}$ ) were formed during intensive insolation and insufficient moisture. $6 \%$ of plants form a third leaf. The leaves are relatively short and narrow. No stolons were found. $28 \%$ of flowering plants (Table 1, 2, 3). Probably the life strategy of this population is based on the implementation of the full life cycle (seeds - seedlings - juvenile plants - immature plants virginal plants - generative plants - senile plants) [27-30]. The seeds were discovered. A large population with occurrence $10 \%$, rate and density of 55.3 pieces per $\mathrm{m}^{2}$ was found at the girder the "Upravitel'stvennaya" in the village of Klimenki. Plants are low-growing $(21.5 \mathrm{~cm})$, and do not form more than two relatively short and narrow leaves. The population does not differ from others by the size of the flower and bulb. There were $38 \%$ of flowering plants, $46 \%$ of all plants formed stolons, no seeds were found (table 1, 2,3). We assume that this population realizes a shortened life cycle based on vegetative reproduction (immature plants, virginal plants-generative plants-senile plants). The population we found in talweg near the village of Klimenki, which is formed by the forest and the girder "Upravitel'stvennaya", is young. There are $5 \%$ of flowering plants, $9 \%$ of table-forming plants. Plants are small: height 23 $\mathrm{cm}$, they form no more than 2 leaves, the leaf length is 20 and $14 \mathrm{~cm}$ with a width of 1.2 and $1.3 \mathrm{~cm}$.

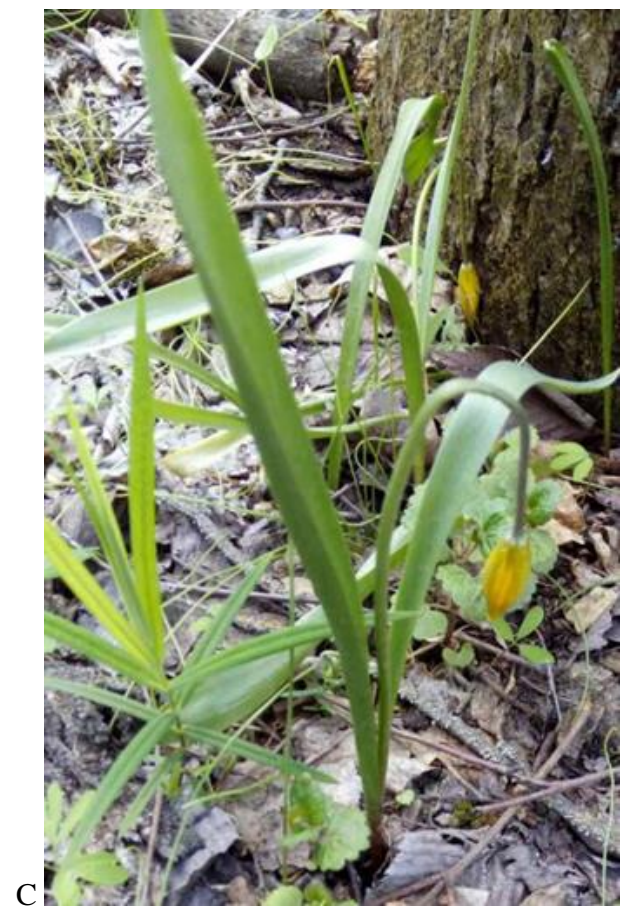

Figure 2: Tulipa biebersteiniana (Photo T. Glubsheva): (A) type of leaves on the inside and outside, (B) a comparison of the size of the leaf, pistil and stamens, and (C) flowering plant under the tree of an adult Acer platanoides

Table 1: Morphometric features of Tulipa biebersteiniana (2018-2020)

\begin{tabular}{|l|l|l|l|l|l|}
\hline Local populations & $\begin{array}{l}\text { Plant length } \\
(\mathbf{c m})\end{array}$ & $\begin{array}{l}\text { Flower length } \\
(\mathbf{c m})\end{array}$ & $\begin{array}{l}\text { Bulb height } \\
(\mathbf{c m})\end{array}$ & $\begin{array}{l}\text { The 1-st leaf } \\
\text { length, }(\mathbf{c m})\end{array}$ & $\begin{array}{l}\text { The 1-st leaf } \\
\text { width, }(\mathbf{c m})\end{array}$ \\
\hline Girder, Victoropol, Rural area & $15.0 \pm 1.01$ & - & $1.5 \pm 0.11$ & $13.4 \pm 0.98$ & $1.0 \pm 0.14$ \\
\hline Forest edge, the city of Biryuch & $20.3 \pm 1.47$ & $2.8 \pm 0.14$ & $2.0 \pm 0.23$ & $16.2 \pm 1.37$ & $1.3 \pm 0.10$ \\
\hline Girder, "Upravitel'stvennaya” & $21.5 \pm 1.5$ & $2.6 \pm 0.16$ & $2.0 \pm 0.20$ & $15.1 \pm 0.75$ & $1.9 \pm 0.09$ \\
\hline Tallweg, Klimenki, Rural area & $23.3 \pm 1.18$ & $3.2 \pm 0.12$ & $2.0 \pm 0.15$ & $20.2 \pm 1.15$ & $1.2 \pm 0.14$ \\
\hline Shrub on top of the girder & $26.6 \pm 1.28$ & $2.9 \pm 0.10$ & $2.0 \pm 0.13$ & $23.3 \pm 1.08$ & $1.7 \pm 0.11$ \\
\hline New road roadside & $33.3 \pm 2.36$ & $3.0 \pm 0.11$ & $2.7 \pm 0.26$ & $20.1 \pm 1.10$ & $2.6 \pm 0.79$ \\
\hline Forest, Klimenki, Rural area & $32.9 \pm 1.68$ & $3.0 \pm 0.11$ & $2.7 \pm 0.24$ & $2.0 \pm 1.41$ & $2.6 \pm 0.50$ \\
\hline
\end{tabular}


Table 2: Numerical characteristics of Tulipa biebersteiniana populations (2018-2020)

\begin{tabular}{|l|l|l|l|l|}
\hline Local populations & S (ha) & Density $\left(\mathbf{P C s} / \mathbf{m}^{2}\right)$ & Occurrence $(\%)$ & Number $(\mathbf{P C s})$ \\
\hline Girder,Victoropol, rural area & 0.95 & $47.0 \pm 0.54$ & 7 & 31250 \\
\hline Tallweg,Klimenki, rural area & 0.88 & $18.6 \pm 0.23$ & 16 & 2620 \\
\hline Shrub on top of the girder Malobykovo rural area & 0.02 & $22.5 \pm 0.32$ & 28 & 1250 \\
\hline forest edge, the city of Biryuch & 1.08 & $30.5 \pm 0.45$ & 10 & 32900 \\
\hline Girder "Upravitel'stvennaya" & 0.5 & $55.3 \pm 0.43$ & 10 & 27650 \\
\hline New road roadside, city of Biryuch & 2.2 & $10.3 \pm 0.83$ & 17 & 3850 \\
\hline Forest, Klimenki, rural area & 0.7 & $35.35 \pm 0.45$ & 40 & 98980 \\
\hline
\end{tabular}

Table 3: Life strategy of Tulipa biebersteiniana (2018-2020)

\begin{tabular}{|l|l|l|}
\hline Local populations & Flowering $(\boldsymbol{\%})$ & Number of stolons $(\%)$ \\
\hline Girder,Victoropol, rural area & - & 44 \\
\hline Tallweg,Klimenki, rural area & 5 & 9 \\
\hline Shrub on top of the girder Malobykovo rural area & 11 & 44 \\
\hline Forest edge of the Budennovskij forest, the city of Biryuch & 28 & 0 \\
\hline Girder "Upravitel'stvennaya" & 38 & 46 \\
\hline New road roadside, city of Biryuch & 52 & 11 \\
\hline Forest, Klimenki, rural area & 65 & 30 \\
\hline
\end{tabular}

The predominance of single-leaved and non-flowering plants without stolons (juvenile) indicates the implementation of a full life cycle based on seed propagation. The population is developing, but is still small with a $16 \%$ of occurrence and a density of 47.0 units per $\mathrm{m}^{2}$ (Table 1, 2, 3).

In the shrub on the top of the beam at the village of Malobykovo, the smallest (1250 pieces) population of Tulipa biebersteiniana was found with an occurrence of $28 \%$ and a density of 22.5 pieces per $\mathrm{m}^{2}$ (Table 1,2,3). The life spectrum is left-sided, flowering plants is only $11 \%$, while stolonforming plants is $44 \%$. The stable presence of the population for more than 20 years in this place indicates the predominance of vegetative reproduction in the life cycle. Plants are about 27 $\mathrm{cm}$ tall and can form a third leaf. The length of the first leaf is $23 \mathrm{~cm}$, the second is $13 \mathrm{~cm}$, the third is $10 \mathrm{~cm}$ with a width of $1.7 \mathrm{~cm}, 1.3 \mathrm{~cm}, 0.8 \mathrm{~cm}$, respectively. One of the discovered populations was located on the side of a new road. We have identified tall plants $(33 \mathrm{~cm})$ with a large bulb $(2.7 \mathrm{~cm}$ in diameter) that can form the third leaf. This population has a right-sided age spectrum ( $52 \%$ of flowering plants). The soil in which Tulip grew land previous years was used for the construction of the road. Some small plants probably died, that causes the high average of morphometric values for plants that are under intensive insolation and not sufficiently moistened. The occurrence is $17 \%$ and the density is 10 pieces per $\mathrm{m}^{2}$ (Table 1, 2, 3).

The population in the forest near the village of Klimenki was located directly under the trees (Fig. 3). There are plants with an average height of $33 \mathrm{~cm}$ there. The plants $(15 \%)$ form the third and the fourth leaves. The leaves are longer and wider than in other populations. The population is large with $40 \%$ occurrence and the density of 35.4 pieces per $\mathrm{m}^{2}$ (table $\left.1,2,3\right)$. It has a right-sided age spectrum (65\% of flowering plants). The number of stolon forming plants is $30 \%$.

\section{Conclusion}

The studied populations are different in number. Some populations are numerous and consist of tens of thousands of objects (the girder at the village of Viktoropol, the edge of the forest at the city of Biryuch, the girder "Upravitel'stvennaya", the forest at the village of Klimenki). Others include just over a thousand of pregenerative plants. The average density is 10 -
$55 \mathrm{PCs} / 1 \mathrm{~m}^{2}$, the occurrence also varies from 7 to $40 \%$. The leftside age spectrum dominates in five populations. There are up to $38 \%$ of pregenerative objects in these populations. The predominance of the generative age spectrum $(52 \%$ and $65 \%)$ was found in two populations. The presence of stolon-forming plants indicates a life strategy of expanding the habitat by selfsupport through vegetative reproduction with the rejuvenation of descendants. Based on published data and evaluating the results of our own measurements, we can identify populations that tend to dry habitats. These low-growing plants with fewer relatively small leaves tend to have a steppe morphotype. At the same time, in the shrub, under the forest canopy, there are larger plants with a large number of leaves of the forest morphotype. In general, the studied populations of Tulipa biebersteiniana are in good and excellent condition. The information obtained complements the information about the current geographical distribution and population structure of the species. Perhaps, on the Northern border of the area there are forming processes with adaptation to the steppe and forest types.

\section{Ethical issue}

Authors are aware of, and comply with, best practice in publication ethics specifically with regard to authorship (avoidance of guest authorship), dual submission, manipulation of figures, competing interests and compliance with policies on research ethics. Authors adhere to publication requirements that submitted work is original and has not been published elsewhere in any language.

\section{Competing interests}

The authors declare that there is no conflict of interest that would prejudice the impartiality of this scientific work.

\section{Authors' contribution}

All authors of this study have a complete contribution for data collection, data analyses and manuscript writing.

\section{References}

1. Prisny YuA (ed). Krasnaya kniga Belgorodskoj oblasti. Redkie i ischezayushchie rasteniya, lishajniki, griby $\mathrm{i}$ zhivotnye. 2nd official publication, Belgorod: HSE "Belgu". 2019:668. (In Russian) 
2. Ivashchenko AA. Tyul'pany i drugie lukovichnye rasteniya Kazahstana [Tulips and other bulbous plants of Kazakhstan]. Almaty: HSE. 2005:192. (In Russian)

3. Baranova MV. Mnogoletnie travyanistye rasteniya klassa Odnodol'nye v kollekcii otkrytogo grunta Botanicheskogo sada Petra Velikogo BIN RAN. St. Petersburg: Rostock HSE. 2013:320. (In Russian)

4. Bochantseva ZP. Tyul'pany Morfologiya, citologiya i biologiya [Tulips Morphology, Cytology and biology]. Tashkent: HSE of the Uzbek SSR. 1962:407.

5. Vvedenskiy AI. Flora Rossii [Flora of Russia]. 1935;4:670. (In Russian)

6. HSE. Decorative herbaceous plants for open ground. L.: HSE Nauka. 1977.

7. Van Raamsdonk LWD, De Vries T. Species relationships and taxonomy in Tulipa subgenus Tulipa L., Pl. Syst. Evol. 1995;195:13-44.

8. Cherepanov SK. Sosudistye rasteniya Rossii i sopredel'nyh gosudarstv [Vascular plants of Russia and neighboring States]. Saint Petersburg: HSE Mir I Semya. 1995;992. (In Russian)

9. Knyazev MS, Kulikov PV, Filippov EG. Tyul'pany rodstva Tulipa biebersteiniana (Liliaceae) na YUzhnom Urale [Tulips related to Tulipa biebersteiniana (Liliaceae) in the southern Urals]. Botanic journal. 2001;(3):109-119.(In Russian)

10. Kutlunina NA, Polezhaeva MA, Permyakova MV. Morfologicheskij i geneticheskij (AFLP) analizy vidov tyul'panov rodstva Tulipa biebersteiniana (Liliaceae) [Morphological and genetic (AFLP) analyses of species of tulips related to Tulipa biebersteiniana (Liliaceae)]. Genetics. 2013;49(4):461-471.(In Russian)

11. Bondrea I, Pamfil D, van Heusden S. AFLP as a modern technique for DNA fingerprinting and identification Tulipa cultivars. Bull. USAMV-CN. 2007;63-64

12. Devey ME, Bell JS, Smith DN. A genetic linkage map for Pinusradiata based on RFLP, RAPD and microsatellite markers. Theor.and Applied Genetics. 1996;92:673-679.

13. Nei M. Estimation of average heterozygosity and genetic distance from a small number of individuals. Genetics. 1978;83:583-590.

14. Maunde M, Cowan RS, Stranc P, Fay MF. The genetic status and conservation management of two cultivated bulb species extinct in the wild: Tecophilaea cyanocrocus (Chile) and Tulipa sprengeri (Turkey), Conserv. Genetics. 2001;2:193-201.

15. Qiao Q, Zhang CQ, Milne RI. Population genetics and breeding system of Tupistra pingbianensis (Liliaceae), a naturally rare plant endemic to SW China. J. Systematics and Evolution. 2010;48(1):47-57.

16. Zhang D, Gao L, Yang YP. Genetic diversity and structure of a traditional Chinese medicinal plant species, Fritillaria cirrhosa (Liliaceae) in southwest China and implications for its conservation. Biochem. Systematics and Ecology. 2010;38:236242.

17. Elinevsky AG, Radygina VI, Chaadaeva NN. Rasteniya Belgorodskoj oblasti [Plants of the Belgorod region]. 2004:121. (In Russian)

18. Gusev AV. Materialy k novomu izdaniyu Krasnoj knigi Belgorodskoj oblasti. Rasteniya. Regional'nyj spisok [Materials for the new edition of the red book of the Belgorod region. Plants. Regional list]. Scientific Bulletin, Ser. Natural science. 2014;10 (27):15-22. (In Russian)

19. Chernyavskikh VI, Tokhtar VK, Dumacheva EV, Degtyar OV. Vidovoe raznoobrazie estestvennoj rastitel'nosti na sklonah yuga Srednerusskoj vozvyshennosti i ego vliyanie na produktivnost' soobshchestv [Species diversity of natural vegetation on the slopes of the South of the Central Russian upland and its impact on the productivity of communities]. Modern problems of science and education. 2013;3:424.(In Russian)

20. Chernyavskikh VI, Dumacheva EV, Lisetsky FN, Tsugkiev BG, Gagieva LCh. Floral variety of Fabaceae Lindl. family in gully ecosystems in the south-west of the Central Russian Upland. Bioscience Biotechnology Research Communications. 2019;12(2):203-210.

21. Dumacheva E.V., Cherniavskih V.I., Tokhtar V.K., Tokhtar L.A., Pogrebnyak T.A., Horolskaya E.N., Gorbacheva A.A., Vorobyova O.V., Glubsheva T.N., Markova E.I., Filatov S.V., 2017. Biological Resources Of The Hyssopus L. On The South Of
European Russia And Prospects Of Its Introduction // International Journal of Green Pharmacy,V. 11, no 3, p. 476-480.

22. Dumacheva E.V., Cherniavskih V.I. Gorbacheva A.A. Vorobyova OV, Borodaeva ZA, Bespalova EN, Ermakova LR. Biological resources of the Fabaceae family in the Cretaceous south of Russia as a source of starting material for droughtresistance selection. International Journal of Green Pharmacy, Apr.-Jun., $\quad$ (Suppl). 2018;12(2):354-358. DOI: http://dx.doi.org/10.22377/ijgp.v12i02.1785.

23. Gubanov IA, Novikov VS, Tikhomirov VN. Opredelitel' vysshih rastenij srednej polosy evropejskoj chasti SSSR [Determinant of higher plants of the middle zone of the European part of the USSR]. Moscow. 1981:285. (In Russian)

24. Kotelnikova MG. Osobennosti formirovaniya plodov i semyan u ryabchika russkogo i shahmatnogo i tyul'pana bibershshtejna $\mathrm{v}$ populyaciyah [Features of fruit and seed formation in Russian and chess grouse and bieberstein's Tulip populations]. Bulletin of young scientists and specialists of Samara State University. 2015;2(7):86-91.(In Russian)

25. Kudryavtseva VM. Semennaya produktivnost' tyul'panov [Seed productivity of tulips]. Biology of seeds of introduced plants, Moscow: HSE Nauka. 1985:65-68.(In Russian)

26. Kobozeva EA. Biomorphology and population ecology of bulbous plants in different natural zones of the Volga upland (for example, Tulipa biebersteiniana Shult. Et Shult .fil. and Lilium martagon L.) (PhD Thesis), Moscow. 2010:21. (In Russian)

27. Yandovka LF, Loseva TA. Tulipa biebersteiniana (Liliaceae) redkij vid voflore Tambovskoj oblasti [Tulipa biebersteiniana (Liliaceae) - a pungent species in the flora of the Tambov region]. Bulletin Of Tambov University, Ser. Natural and technical Sciences. 2013;18(1):424-425.(In Russian)

28. Lyu TN, Lidzhieva NTS, Ochirova AA, Kondyshov OYu. Izmenchivost' morfologicheskoj struktury rastenij $\mathrm{v}$ cenopopulyaciyah Tulip abiebersteiniana $\mathrm{v}$ zapovednike "Chernye zemli" [Variability of the morphological structure of plants in the coenopopulations of Tulipa biebersteiniana in the reserve "Black soils"]. In the world of scientific discovery. 2015;10(70):84-90.(In Russian)

29. Mukhavetshina LV, Mullabayeva EZ, Ishmuratova MM Osobennosti biologii I cenopopulyacionnye harakteristiki vidov roda Tulipa na YUzhnom Urale [Features of biology and cenopopulation characteristics of species of the genus Tulipa in the southern Urals]. Bulletin Of Udmurt University, Ser. Biology, Earth Sciences. 2015;25(2):101-108.(In Russian)

30. Ryff LE, Kutlunina NA, Belich TV. Usloviya proizrastaniya populyacij Tulipa biebersteiniana v YUzhnom Krymu [Growing conditions of Tulipa biebersteiniana populations in the southern Crimea]. Ecology of Biosystems: Problems of study, indication and forecasting. 2017:176-182.(In Russian). 